\title{
Kognitív képességek és stratégiai bizonytalanság egy bankrohamkísérletben
}

Tanulmányunkban egy laboratóriumi kísérlet keretében azt vizsgáljuk, hogy a kognitív képességek és a stratégiai bizonytalanság hogyan hat a betétesi döntésekre. Olyan egyedi döntéseket nézünk meg, ahol a betétesnek domináns stratégiája van, azaz függetlenül attól, hogy a többi betétes hogyan döntött, neki a legjobb döntés bennhagyni a pénzét a bankban. Azonban a stratégiai bizonytalanság - azaz az, hogy a megfigyelhető korábbi döntések alapján nem derül ki egyértelmüen, hogy a többi betétes hogyan döntött - megnehezíti a domináns stratégia felismerését. Azt találjuk, hogy egy kognitív képesség mérésére gyakran használt mutatónak van magyarázó ereje a betétesi döntéseket illetően, ha fennáll a stratégiai bizonytalanság, azonban ha nem áll fenn, a mutató elveszíti prediktív erejét.*

Journal of Economic Literature (JEL) kód: C91, D8, G21.

Frank Capra 1946-os klasszikus filmjében Az élet csodaszépben betétesek ezrei tolonganak a bank bejáratánál a pénzüket követelve. A fekete-fehér filmkockák arra utalhatnak, hogy ilyen bankrohamok már a múlt ködébe vesznek, de nem ez a helyzet. A nagy recessziónak nevezett utolsó világgazdasági válság első mozzanata sokak szerint az volt, amikor 2007 szeptemberében a betétesek megrohanták a Northern Rock nevü angol bankot. Ezen roham után több fejlett országban is történtek bankrohamok, például a hongkongi Bank of East Asia, a spanyol Bankia vagy az egyesült államokbeli Washington Mutual esetében is tömeges betétkivétnek lehettünk tanúi. Az utóbbi években pedig előbb Cipruson, majd

* Köszönjük a Magyar Közgazdaságtudományi Egyesület 2014. évi konferenciáján kapott hasznos hozzászólásokat és két anonim bíráló építő megjegyzéseit. Kiss Hubert János hálás az OTKA támogatásáért (PD 105934). A tanulmány a Bolyai János Kutatási Ösztöndíj támogatásával készült. Ismael Rodriguez-Lara és Alfonso Rosa-García hálás a Ministerio de Educación, Cultura y Deporte de Españának a támogatásáért (ECO2014-58297-R és ECO2013-45698).

Kiss Hubert János, Eötvös Loránd Tudományegyetem, az MTA KRTK KTI Játékelmélet kutatócsoportjának tagja.

Ismael Rodriguez-Lara, Middlesex University (London), LUISS Guido Carli University (Róma).

Alfonso Rosa-García, Universidad Católica San Antonio (Murcia).

A kézirat első változata 2015. június 22-én érkezett szerkesztőségünkbe.

DOI: http://dx.doi.org/10.18414/KSZ.2015.10.1030 
2015-ben a görögországi válság idején is szemtanúi lehettünk kígyózó soroknak a bankok előtt. Magyarországon a pénzügyi felügyelet az utóbbi években számos takarékszövetkezetet zárt be súlyos hiányosságok miatt, és a bezárás bejelentésekor több esetben kisebbfajta bankroham alakult ki. A Buda Cash- és a Quaestorbotrányok kapcsán is rengeteg befektető igyekezett menteni a menthetőt, és sietett kivenni a pénzét, legtöbbször már megkésve.

Bankrohamszerü jelenségeket nem csak betétesek idéztek elö, és nem csak bankokban fordultak elö. Például a Northern Rock esetében a betétesi roham előtt az egyéb forrásokat nyújtó befektetők nem újították meg a befektetéseiket a bankban, és ez vezetett elöször problémákhoz (Shin [2009]). A pénzügyi piacokon is lezajlottak rohamszerü események, például Gorton-Metrick [2012] a repopiacon tapasztalt banki szakemberek közötti rohamot elemzi.

A bankrohamoknak két fö magyarázata van. Egyes szerzők (például Gorton [1988], Calomiris-Mason [2003]) a gazdasági feltételek romlásával és a bank fundamentális jellemzőinek alakulásával magyarázzák a bankrohamok bekövetkezését. Rossz gazdasági helyzetben vagy rosszul müködő bankok esetén a betétesek kevésbé bíznak abban, hogy visszakapják a pénzüket, és ez ahhoz vezethet, hogy tömegesen kivegyék a betett összegeket a bankból.

A másik magyarázat szerint a bankrohamokat a betétesek által játszott koordinációs játék rossz kimenetelének tekinthetjük. Diamond-Dybvig [1983] klasszikus cikkében a bank fundamentálisan jó, a betétesek pedig egy szimultán játékot játszanak, amelynek során arról kell dönteni, hogy kivegyék-e a pénzüket, vagy inkább hagyják a bankban. Ha egy betétes azt gondolja, hogy a többiek kiveszik a pénzüket, akkor arra az a legjobb válasz, ha ő is igyekszik kivenni a pénzét a bankból. Ez egy bankrohammal járó egyensúlyhoz vezet. A jó, bankroham nélküli egyensúlyban a betétesek vélekedése a többiekröl az, hogy nem veszik ki a pénzüket, és ekkor a legjobb válasz az, ha a likviditási gondokkal nem küszködő betétes nem veszi ki a pénzét.

Mindkét magyarázatot alátámasztják valós bankrohamokban tapasztalt fejlemények. Egyrészt, válságokban gyakoribbak a bankrohamok, és rosszabb bankokat is inkább rohannak meg a betétesek. Másrészt, a Northern Rock-roham kapcsán az egyik betétes a következőket mondta:

„Nem az van, hogy nem hiszek a Northern Rockban, de mindenki aggódik, és nem akarok az utolsó lenni a sorban. Ha mindenki más is ezt teszi (sorban áll, hogy kivegye a pénzét), akkor ez a leghelyesebb, amit tehetünk." (Livesey-Menon [2007].)

E szavak a koordinációs magyarázatot támasztják alá. Számos tanulmány mutatja be, hogy akkor is voltak bankpánikok, amikor a gazdasági helyzet nem volt rossz (Ennis [2003]), illetve jó fundamentumokkal rendelkezö bankokat is megrohantak (Davison-Ramirez [2014], De Graeve-Karas [2014]).

Az utóbbi években a megszaporodott bankrohamok miatt újfajta magyarázatok és kutatási módszerek is megjelentek. A módszerek közül talán a kísérleti közgazdaságtan eszköztára a legfontosabb. A valós életben azt látjuk, hogy valaki kiveszi a pénzét, azt azonban nem tudjuk, hogy miért tette azt. Likviditási gondjai voltak? Nem bízott a bankban? Pánikba esett, amikor azt látta, hogy sokan 
kiveszik a pénzüket? A kontrollált körülmények között végzett kísérletek során számos magyarázat kiszűrhető, és pontosabb képet nyerhetünk a betétesi döntések mozgatórugóiról.

Például Garratt-Keister [2009] egy kísérlet segítségével többek között azt tanulmányozta, hogy miként hat a betétesek döntésére, ha többször dönthetnek, és a döntések között megfigyelhetö, hogy a többi kísérleti alany közül hányan vették ki a pénzüket a bankból. A szerzők azt találták (amit azután későbbi kísérleti tanulmányok is megerősítettek), hogy minél több másik alany veszi ki a pénzét, annál valószínübb, hogy az adott alany is kiveszi majd. Ez az eredmény arra hívja fel a figyelmet, hogy fontos lehet a bankrohamok kialakulásában (és azok kivédésében), hogy milyen információ jut el a betétesekhez a többi betétes döntéséről.

Dijk [2014] az aggodalom hatását vizsgálja szintén kísérleti keretek között. Mielőtt arról kellene dönteniük a kísérletben részt vevőknek, hogy kiveszik-e a pénzüket vagy sem, Dijk különböző pszichológiai helyzeteket idézett elö. Azt találta, hogy amikor félelmet indukált a résztvevőkben (vissza kellett emlékezniük, és részletesen le kellett írniuk életük egy olyan epizódját, amikor nagyon féltek), akkor a betétkivétek aránya jóval magasabb volt, mint a másik esetben, amikor egy nagyon boldog pillanatot kellett felidézniük.

Mi is kísérleti keretek segítségével vizsgálunk egy lehetséges magyarázatot, a betétesek racionalitását. A standard közgazdasági elmélet felteszi, hogy az egyének racionálisak és optimális döntéseket hoznak. Mindennapi tapasztalat és közgazdasági kísérletek is azt mutatják, hogy ez nem mindig van így. Lehetséges, hogy a bankrohamokhoz vezető döntések egy része egyszerüen annak tudható be, hogy a betétesek nem hoznak racionális döntést. Korábbi tanulmányunkhoz (Kiss és szerzőtársai [2014b]) felhasznált kísérletben kapott döntéseket használunk fel a kérdés vizsgálatához. A kísérlet alapja a Diamond-Dybvig [1983] modellje, amelyben a bankroham koordinációs problémaként merül fel.

A bankot a mi esetünkben két türelmes és egy türelmetlen betétes alkotja. Elöbbieket nem éri likviditási sokk, így nekik nincs szükségük a bankba elhelyezett pénzükre, míg a türelmetlen betétesnek ki kell vennie a megtakarítását, mert szüksége van a pénzére. A betétesek típusa azonban nem figyelhető meg nyilvánosan, így a türelmes betétesek is kivehetik a pénzüket ahelyett, hogy bennhagynák a bankban, ahol az kamatozhatna. Kísérletünkben a türelmetlen betétest a számítógép szimulálta, míg a türelmes betétesek valódi személyek voltak. Ök különböző információs környezetben döntöttek arról, hogy bennhagyják-e a pénzüket, vagy kiveszik a bankból.

Az információs környezetek abban különböztek, hogy hányadikként hozták meg a döntést (első, második vagy harmadik pozícióban, amely exogén módon adott volt), megfigyelhették-e a korábbi döntéseket, és tudták-e, hogy az utánuk következő játékos(ok) megfigyelik-e az ő döntéseiket. A türelmes betétesek akkor kapták a legmagasabb kifizetést, ha mindketten bennhagyták a pénzüket a bankban, azonban jobban megérte kivenni a pénzt az első két pozícióban, mint egyedüliként bennhagyni. A kifizetések szerkezetéből adódóan az utolsó pozícióban domináns stratégia volt bennhagyni a pénzt a türelmes betéteseknek. A stratégiai 
bizonytalanság (esetünkben konkrétan az, hogy milyen döntést hozott a másik türelmes betétes) azonban megnehezítheti a döntést. ${ }^{1}$

Egyrészt, könnyebben belátható, hogy a legjobb döntés bennhagyni a pénzt a bankban, ha egyértelmüen megfigyelhetö, hogy a másik türelmes betétes is így tett. Például, ha az utolsóként döntő türelmes betétes látja az összes korábbi döntést, és azt is látja, hogy valaki bennhagyta a pénzét a bankban, akkor könnyü kitalálni, hogy a kifizetése akkor lesz maximális, ha bennhagyja a pénzét a bankban. Viszont ha az utolsó pozícióban döntő játékos nem lát egy korábbi döntést sem, akkor végig kell gondolnia, hogy a másik türelmes játékos döntéseire külön-külön mi a legjobb válasz, és be kell látnia, hogy mindkét esetben az a legjobb, ha bennhagyja a pénzét. Ez utóbbi bonyolultabb gondolatmenetnek tủnik, mint az a helyzet, amikor a másik türelmes betétes adott döntése mellett kellett csak összehasonlítani a saját döntés kifizetésbeli következményeit.

Másrészt, a stratégiai bizonytalanság kifizetésbeli bizonytalansággal is jár. Mivel a kifizetés függ a többi betétes kifizetésétől, így az utolsó pozícióban döntő betétes, aki nem látja a korábbi döntéseket, bizonytalan, hogy a döntése milyen kifizetést fog eredményezni. Ez a bizonytalanság vezethet nem optimális döntésekhez.

Fontos megjegyezni, hogy a domináns stratégia miatt a stratégiai bizonytalanság nem számít az optimális döntés szempontjából. Ha mégis számít, az annak a jele, hogy a kísérleti alanyok nem teljesen racionális döntéseket hoztak. Úgy véljük, hogy a stratégiai bizonytalanság fogalma segít annak megértésében, mitől függ az, hogy nem optimális döntéseket hoznak a kísérleti alanyok. ${ }^{2}$

Mint említettük, egy korábbi kísérletünk (Kiss és szerzőtársai [2014b]) adatait használjuk fel a jelen tanulmányban. ${ }^{3}$ Az utolsó pozícióban hozott döntésekre koncentrálunk, mivel ott a domináns stratégia miatt teljesen egyértelmü, hogy mi az optimális döntés. A racionalitást a Frederick [2005] által megalkotott kognitív reflexiós teszt (cognitive reflection test, CRT) segítségével mérjük. A CRT három kérdésből áll, és mindhárom kérdésre a legtöbb embernek azonnal beugrik egy válasz. Ez a válasz azonban általában rossz, és a kognitív képességeket mozgósítani kell, hogy megtaláljuk a helyes választ. Esetünkben a teszt segítségével azt próbáljuk megérteni, mi magyarázhatja azt, hogy nem a domináns stratégiát választja a betétes. Az is célunk, hogy megértsük, mi magyarázhatja a rossz választást. Az elmondottak alapján azt várjuk, hogy 1 . a jobb kognitív képességekkel rendelkező betétesek kevésbé térnek el a domináns stratégiától, és 2 . a stratégiai bizonytalanság elősegíti a nem domináns stratégia választását.

\footnotetext{
${ }^{1}$ Heinemann-Nagel-Ockenfels [2009] által használt definíció („....a stratégiai bizonytalanságot mint az interaktív döntési helyzetben céltudatos viselkedésű játékosok bizonytalanságát határozzuk meg”) alapján használjuk mi is a stratégiai bizonytalanság fogalmát (182. o.).

${ }^{2}$ Köszönjük az egyik bírálónk megjegyzését, aki felhívta a figyelmünket annak szükségességére, hogy pontosan tisztázzuk a stratégiai bizonytalanság és a domináns stratégia viszonyát.

${ }^{3}$ Kiss és szerzőtársai [2014b] azt a kérdést vizsgálta kísérletileg, hogy a nők hajlamosabbak-e kivenni a pénzüket a bemutatott játékban. Viselkedés-gazdaságtani eredmények alapján azt várhatjuk, hogy igen a válasz, azonban mi nem találtunk ilyen hatást. Abban a tanulmányban minden pozíciót és információs struktúrát megvizsgáltunk, de nem foglalkoztunk a kognitív képességekkel.
} 
Azt találjuk, hogy a kísérletben részt vevők túlnyomó többsége felismeri a domináns stratégiát, hiszen mindössze az esetek 10 százalékában veszik ki az utolsóként döntő játékosok a pénzüket. Több rossz döntést hoznak a játékosok olyan helyzetekben, amikor stratégiai bizonytalanság áll fenn. A jobb kognitív képességekkel rendelkezö kísérleti alanyok ilyenkor is kevésbé vették ki a pénzüket. Amikor nem volt stratégiai bizonytalanság, a CRT-ben megmutatkozó különbségeknek nem volt prediktív erejük a döntéseket illetően.

A tanulmány következő részében röviden áttekintjük az irodalmat. Majd bemutatjuk a bankrohamjátékot, illetve a kísérletet. Azután az eredményeket ismertetjük, majd levonjuk a következtetéseket.

\section{Irodalmi áttekintés}

A pénzügyek területén számos olyan tanulmány születet, amely azt dokumentálja, hogy az egyének nem hoznak racionális döntéseket. Például Gerardi és szerzőtársai [2013] szerint a gazdasági válság kialakulásában jelentős szerepük volt a rossz gazdasági döntéseknek. Számos tanulmány foglalkozott azzal, hogy nem optimális döntéseink következtében nem takarítunk meg eleget a nyugdíjas évekre (például Choi és szerzőtársai [2011], van Rooij és szerzötársai [2011]). Bertrand-Morse [2011] azt mutatta be, hogy bár könnyü információt szerezni a hitelek feltételeiről, sokan mégis túl drága hiteleket vesznek fel.

Kísérleti körülmények között sok esetben nagyon pontosan meghatározható, hogy egy döntés racionális-e, vagy sem, illetve a kísérletek során a kognitív képességeket is jól lehet mérni. Casari és szerzőtársai [2007] kísérleti árveréseken hozott döntéseket tanulmányoztak, és azt találták, hogy azon résztvevők, akik magasabb pontszámot értek el egyetemi felvételin (és így valószínűleg jobb kognitív képességekkel rendelkeznek), kevésbé szenvednek a győztes átkától, mint azok, akiket alacsonyabb pontszámmal vettek fel. Különböző kísérletekben azt is megfigyelték, hogy a kognitív képességek hatással vannak a stratégiai gondolkodásra (Carpenter és szerzőtársai [2013], Brañas-Garza és szerzőtársai [2012], Rydval és szerzőtársai [2009]). A kognitív képességeknek a viselkedési közgazdaságtanban is fontos szerepük van, hiszen korrelálnak bizonyos viselkedési anomáliákkal, mint például a horgonyhatással (Bergman és szerzötársai [2010]) vagy az összekapcsolási téveszmével (conjunction fallacy-Oechssler és szerzőtársai [2009]).

A pénzügyi döntések területén is egyre több tanulmány lát napvilágot a kognitív képességek és a pénzügyi döntések összefüggéseiről (lásd például Korniotis-Kumar [2010] összefoglaló tanulmányát). E tanulmányok megmutatják, hogy a kognitív képességek összefüggnek a buborékokkal (Corgnet és szerzötársai [2015]), a megtakarításokkal (Ballinger és szerzötársai [2011]) és a fogyasztási és beruházási döntésekkel (Insler és szerzőtársai [2015]). Több tanulmány is azt találta, hogy a részvényvásárlás (amit gyakran a pénzügyi döntések kifinomultságával hoznak összefüggésbe) is pozitívan korrelál az intelligenciahányadossal (Christelis és szerzőtársai [2010], Benjamin és szerzőtársai [2013]). Továbbá Grinblatt és szerzötársai [2012] és Korniotis-Kumar 
[2013] szerint is a jobb kognitív képességekkel rendelkező egyének pénzügyi döntései (például milyen részvényeket választ, mikor ad vagy vesz adott értékpapírt) jobb eredménnyel járnak, mint a rosszabb képességü befektetőké.

Mi egy olyan pénzügyi döntést vizsgálunk, amelyről nem szólnak az előző tanulmányok. A CRT-t használjuk a kognitív képességek méréséhez, és segítségével igyekszünk megérteni, hogy e képességek meg tudják-e magyarázni a tanulmányozott betétesi döntések optimalitását. A kognitív képességek átfogó fogalmát, annak összes dimenzióját egy egyszerü teszt nem képes megragadni, azonban Toplak és szerzötársai [2011] megmutatta, hogy a CRT pozitívan korrelál a megszokott kognitív képességet mérö tesztekkel. Frederick [2005] kiemelte, hogy a teszt azt ragadja meg, hogy az egyének mennyire képesek ellenállni annak, hogy egy kezdetben jónak tűnő, de nem átgondolt és hibás választ elfogadjanak. Pénzügyi válságok idején az emberek gyakran esnek kétségbe, és sokszor túl gyorsan és meggondolatlanul döntenek, így a CRT alkalmasnak tünik ezen elhamarkodott döntések megértésére is.

\section{A bankrohamjáték}

Két türelmes és egy türelmetlen betétes alkot egy bankot. Mindegyikük elhelyez $t=0$ időpontban 80 ECU betétet a bankban, amely így 240 ECU-t ruházhat be. ${ }^{4}$ Egyetlen kockázatmentes beruházás áll a bank rendelkezésére. A beruházás fix megtérülést ad $t=2$-ben, de fel is lehet számolni likvidálási költségek nélkül $t=1$-ben. Utóbbi esetben a beruházás nettó hozama nulla.

A betétesek a $t=1$ időpontban arról döntenek egymás után, hogy kiveszik-e a pénzüket, vagy pedig bennhagyják a bankban. A döntési sorrendet exogén módon határozzuk meg, bármely pozícióba kerülésnek ugyanakkora valószínűsége van. Ha egy betétes kiveszi a pénzét $t=1$ időpontban, akkor 100 ECU-t kap, amennyiben a bankban van ennyi pénz. Esetünkben, ha az első vagy második pozícióban döntő betétes kiveszi a pénzét, akkor biztosan kap 100 ECU-t. Ha azonban a harmadik betétes szeretné ugyanezt tenni, miután elötte ketten már kivették a pénzüket, akkor ő csak a maradék 40 ECU-t $[240-(2 \times 100)]$ kapja meg. Ha a harmadik betétes kiveszi a pénzt, és senki vagy csak egy betétes vette elötte ki a pénzét, akkor a bank 100 ECU-t fizet neki.

Azok a betétesek, akik bennhagyják a pénzüket a bankban, csak a $t=2$-edik időpontban kapják meg a kifizetésüket, amelynek nagysága attól függ, hogy összesen hányan döntöttek hasonlóképpen. Ha csak egy betétes nem vette ki a pénzét, akkor ő $t=2$-ben 60 ECU-t kap, ha azonban mindkét türelmes bennhagyta a pénzét, akkor mindketten 140 ECU-t kapnak. Ez a kezdeti 80 ECU és annak kamatai. A DiamondDybvig [1983] modellt követve a türelmetlen játékos mindig kiveszi a pénzét. Nincs bizonytalanság a likviditási típusokat tekintve, azaz köztudomású, hogy két türelmes és egy türelmetlen betétes alkotja a bankot.

A türelmes játékosnak a modellben akkor éri meg bennhagyni a pénzét, ha tudja, vagy ha úgy vélekedik, hogy a másik türelmes játékos is így tesz. Modellünk

\footnotetext{
${ }^{4}$ A kísérleti közgazdaságtanban a kísérleti pénznemet ECU-nek (experimental currency unit) hívják.
} 
megengedi, hogy a korábbi döntéseket is megfigyelhessék a játékosok az információs struktúra függvényében. Konkrétan minden lehetséges helyzetet tanulmányozunk a megfigyelhetőség szempontjából. Tehát adott pozícióban lévő betétes vagy látja az előtte döntő betétes(ek) döntését, vagy sem, és azt is tudja, hogy az utána következő betétes(ek) látják-e az ő döntését. Empirikus tanulmányok (például Kelly-O Grada [2000], Starr-Yilmaz [2007], Iyer-Puri [2012]) alapján egyértelmü, hogy a megfigyelhetöség nagyon fontos a betétesi döntésekben, ezért építettük bele $\mathrm{mi}$ is az egyszerű modellünkbe. A megfigyelhetőséggel kapcsolatos információkat (mit lát ő, és ki látja őt?) $t=1$ elején tudják meg a betétesek.

Lássuk kicsit részletesebben az információs struktúrát! Tekintsünk két betétest, az $i$-ediket és a $j$-ediket, $i, j \in\{1,2,3\}$ és $j>i$. Ha az $i$-edik betétes döntését megfigyelheti a $j$-edik betétes, és ezt az $i$-edik betétes is tudja, akkor a kettejük között létezik az $i j$ él. Egy betétesi hálózat (vagy információs struktúra) pedig nem más, mint a betétesek közötti élek halmaza. Például a teljes hálózatban minden lehetséges él megtalálható, azaz ez a hálózat leírható a következőképpen: $(12,23,13)$. Összesen nyolc lehetséges hálózat létezik: $(12,23,13),(12,23),(12,13),(13,23),(12),(13),(23)$ és $(\varnothing)$, ahol $(\varnothing)$ az üres hálózatot jelöli, amelyben egy él sem található.

A megfigyelhetőséggel kapcsolatos a stratégiai bizonytalanság, ugyanis minél kevesebb korábbi döntés figyelhető meg, annál nagyobb a bizonytalanság azt illetően, hogy hogyan döntött a másik türelmes betétes. Számunkra ebből a szempontból a harmadikként döntést hozó türelmes betétes az érdekes. Ha ez a betétes egyetlen korábbi döntést sem lát, vagy azt látja, hogy valaki kivette a pénzét, akkor fennáll a stratégiai bizonytalanság. Az első esetben egyértelmü, hogy nem tudja, hogyan döntött a másik türelmes betétes, míg a második esetben bizonytalan, hogy a pénzt a türelmetlen betétes vagy a másik türelmes betétes vette ki. Az összes többi lehetséges esetben nincs stratégiai bizonytalanság. Három ilyen eset van: az látható, hogy 1 . egy betétes bennhagyta a pénzét; 2 . egy betétes bennhagyta a pénzét, míg a másik kivette; 3. mindkét betétes kivette a pénzét. Az 1. táblázat összefoglalja az információs struktúrákat és azt, hogy van-e stratégiai bizonytalanság.

\section{1. táblázat}

Információs struktúrák és stratégiai bizonytalanság

\begin{tabular}{llc}
\hline $\begin{array}{l}\text { Mit láthat } \\
\text { a harmadik betétes? }\end{array}$ & \multicolumn{1}{c}{ Pontos információ } & $\begin{array}{c}\text { Stratégiai } \\
\text { bizonytalanság }\end{array}$ \\
\hline $\begin{array}{l}\text { Mindkét korábbi } \\
\text { döntést látja }\end{array}$ & Mindketten kiveszik a pénzüket & Nincs \\
\hline Csak egy korábbi & Kiveszi a pénzét & Nincs \\
döntést figyel meg & Bennhagyja a pénzét & Van \\
\hline Semmit sem lát & - & Nincs \\
\hline
\end{tabular}

E modell alapján a következő állítás könnyen belátható. ${ }^{5}$

\footnotetext{
${ }^{5}$ A modell részletesebb kifejtése és elemzése a Kiss és szerzőtársai [2014a] tanulmányban található.
} 
ÁLLÍTÁs • A harmadik pozícióban döntést hozó betétesnek domináns stratégiája van, ha türelmes, és függetlenül attól, hogy mit figyel meg, érdemes bennhagynia a pénzét a bankban.

Bizonyítás - Mivel a türelmetlen betétes mindig kiveszi a pénzét, így a harmadik pozícióban döntést hozó türelmes játékos elött vagy 1 . ketten vették ki a pénzüket, vagy 2 . az egyik betétes bennhagyta a pénzét, míg a másik kivette. A kifizetések ismeretében könnyü megmutatni, hogy mindkét esetben a legjobb döntés bennhagyni a pénzt, ami ezért domináns stratégia. Az első esetben, ha bennhagyja a pénzt, akkor 60 ECU-t kap 40 ECU helyett, míg a másodikban 140 ECU-t 100 ECU helyett.

A bankrohamjáték alapja Diamond-Dybvig [1983] cikke, amely a bankrohammal járó egyensúly lehetséges megszüntetését is tárgyalja. Az egyik lehetséges mód a betétbiztositás bevezetése, amire úgy is tekinthetünk, mint egy olyan intézményre, amely azt szolgálja, hogy a betétesek minél inkább azt a stratégiát tekintsék dominánsnak, amelyikben megtakarításaikat bennhagyják a bankban. ${ }^{6}$

A megfigyelhetőség függvényében azonban nehezebb lehet megtalálni az előző eredményt. Ha a harmadik helyen döntő türelmes játékos azt látja, hogy 1. valaki bennhagyta a pénzét, vagy 2 . valaki bennhagyta, míg a másik betétes kivette a pénzét, akkor csupán a pénz bennhagyásával elérhető 140 ECU-t kell összehasonlítani a betétkivéttel járó $100 \mathrm{ECU}$-vel, és könnyen látszik, hogy az első döntés maximalizálja a kifizetést. Ha azt látja ez a betétes, hogy az elöző két betétes kivette a pénzét, akkor tudja, hogy a másik türelmes betétes biztosan kivette a pénzét. Ekkor ismét a pénz bennhagyásával elérhető 60 ECU-t hasonlítja össze a betétkivéttel járó 40 ECU-vel, és arra jut, hogy az első döntés maximalizálja a kifizetést.

Ha azonban csupán egy betétkivétet figyel meg, akkor nem tudja, hogy az a türelmes vagy a türelmetlen betétes döntése. Ekkor végig kell gondolnia azt, hogy mi a legjobb akkor, ha a másik türelmes betétes bennhagyta a pénzét, és mi a legjobb akkor, ha kivette. A két lehetséges forgatókönyv végiggondolása és annak belátása, hogy mindkét esetben a legjobb döntés bennhagyni a pénzt a bankban, nehezebbnek tünhet. Hasonló a helyzet akkor is, ha egyetlen korábbi döntést sem figyel meg a harmadikként döntést hozó betétes.

A kísérlet során kapott adatok alapján azt vizsgáljuk, hogy a harmadikként döntö türelmes betétesek racionálisak-e, és követik-e a domináns stratégiát. Arra is kíváncsiak vagyunk, hogy a döntések megfigyelhetősége hogyan befolyásolja a döntéseiket. Konkrétabban, a stratégiai bizonytalanság megnehezíti-e az optimális döntés megtalálását. Az előző bekezdésben leírtak alapján azt várjuk, hogy kevesebb esetben hoznak nem optimális döntést a betétesek, ha nincs stratégiai bizonytalanság. $\mathrm{Az}$ is érdekes kérdésnek tünik, hogy a CRT által mért kognitív képességeknek van-e

${ }^{6}$ Köszönjük az egyik anonim bírálónak, hogy felhívta a figyelmünket erre az értelmezésre.

Diamond és Dybvig betétbiztosítási modelljét erősen kritizálja Wallace [1988] és a későbbiekben nem is ezt a modellt használják a betétbiztosítás tanulmányozásához. A betétbiztosításról magyarul lásd Harmati és szerzőtársai [1996] müvét. 
elörejelző szerepük azt illetően, hogy milyen döntést hoznak a betétesek a harmadik pozícióban. Az a kérdés is felmerül, hogy a stratégiai bizonytalanság és a kognitív képességek összefüggnek-e.

\section{A kísérlet}

A valenciai egyetem (Universitat de Valencia) LINEEX nevü kísérleti laboratóriumában végeztük el a kísérletet 2013 júliusában. Két kísérleti alkalom volt, összesen hatvan résztvevővel. A kísérleti alanyok nem vettek még részt koordinációs játékkal vagy pénzügyi döntésekkel kapcsolatos kísérletben. Az összes résztvevő az egyetem közgazdaságtani vagy gazdálkodási alapszakos hallgatója volt.

A kísérlet három próbakörrel kezdődött, amelyek során a résztvevők megismerkedtek a döntési helyzettel. Ezek után 15 körön keresztül hoztak döntéseket. Minden kör elején a résztvevőket véletlenszerűen újracsoportosítottuk. Köztudott volt, hogy minden körben egy másik résztvevővel és a számítógéppel alkotnak egy bankot, és a számítógép (a türelmetlen betétest imitálva) mindig kiveszi a pénzét. A résztvevők a modell ismertetése során bemutatott kifizetések és egyéb paraméterek által meghatározott környezetben hozták meg a döntéseiket. Minden kör elött kaptak információt arról, hogy az elöző körben mi történt a bankjukban (hányan vették ki a pénzüket és mennyi volt a kifizetésük). A Függelékben található egy számítógépes ábra egy olyan döntésről, amit egy harmadik pozícióban döntést hozó játékos látott a kísérlet során.

Minden kísérleti alkalom megközelítően 90 perces volt, a résztvevők átlagosan 15 eurót nyertek, amely tartalmazta a 3 eurós megjelenési díjat is. A végső kifizetések megállapítása úgy történt, hogy minden résztvevőnek véletlenszerủen kiválasztottunk egy kört, és az abban a körben elért kifizetését kapta meg 10 ECU = 1 euró átváltás mellett.

A kísérlet végén a résztvevők egy kérdőívet is kitöltöttek, amelynek segítségével többletinformációt gyüjtöttünk a résztvevők neméről, kockázatkerüléséről és kognitív képességéről. A kockázatkerülést a Gneezy-Potters [1997] nevével fémjelzett beruházási kérdéssel mértük. E szerint minden résztvevő hipotetikusan kap 10 eurót és azt kellett megmondaniuk, hogy ebből az összegből mennyit akarnak beruházni egy kockázatos projektbe. Ez a projekt 50 százalékos valószínűséggel minden beruházott euró után 2,5 eurót ad vissza, 50 százalékos valószínűséggel azonban elveszik a beruházott összeg. A be nem ruházott rész a résztvevőé marad. A beruházás várható értéke pozitív, és nő a beruházott összegben, így egy kockázatsemleges (vagy kockázatszeretö) egyén a teljes összeget beruházná, míg a kockázatkerülő alanyok kevesebbet. A be nem ruházott összeg nagysága a kockázatkerülés egyik lehetséges méröszáma.

A kognitív képességek mérésére a kérdőív tartalmazta Frederick [2005] kognitív tesztjét. Ez a teszt a következő három kérdést tartalmazza:

1. Egy ütő és egy labda együtt 1,1 dollárba kerül. Az ütő 1 dollárral többe kerül, mint a labda. Mennyibe kerül a labda? 
2. Ha öt gép öt perc alatt készít öt kütyüt, akkor mennyi idő alatt készít 100 gép 100 kütyüt?

3. Egy tóban a tavirózsa mindennap a kétszeresére nő. Ha 48 nap alatt lepi el az egész tavat a növény, akkor hány nap alatt lepi el a felét?

A teszten elért pontszám (egy helyes válasz egy pontot ér) erősen korrelál az intelligenciatesztek pontszámával. A tesztet számos egyetemen elvégezték. Az MIT-n az átlagos pontszám 2,18 volt, a Princetonon és a Harvardon 1,5 körüli volt és számos helyen a pontszám az egyet sem érte el. ${ }^{7}$

A kísérlet végi kérdőív kitöltésére bőven hagytunk időt, nem sietettük a kísérleti alanyokat. A legtöbb időt felhasználó résztvevő sem töltött negyedóránál többet a kérdőív kitöltésével.

\section{Eredmények}

Hatvan kísérleti alany 15 körben hozott döntéseket, így 900 megfigyelésünk van. A döntési sorban elfoglalt pozíció véletlenszerüen lett meghatározva minden kör elején. Összesen 299/289/312 megfigyelésünk van az elsö/második/harmadik helyen hozott döntésekre. Ebben a tanulmányban csak az utóbbi döntésekre koncentrálunk, hiszen a harmadik helyen a résztvevőknek domináns stratégiájuk van.

A 2. táblázatban a mintánk alapvető leíró statisztikáit mutatjuk be.

\section{2. táblázat}

Leíró statisztikák

\begin{tabular}{lcc}
\hline & Átlag & Szórás \\
\hline 1. Szociodemográfiai mutatók & & \\
Kockázatkerülés & 5,58 & 1,80 \\
Nem (=1, ha nő) & 0,50 & 0,50 \\
Kognitív képességek (CRT-pontszám) & 0,57 & 0,98 \\
\hline 2. Döntések & & \\
Betétkivételi arány & 0,10 & 0,31 \\
Betétkivételi arány (nincs stratégiai bizonytalanság) & 0,04 & 0,19 \\
Betétkivételi arány (van stratégiai bizonytalanság) & 0,17 & 0,38 \\
Betétkivételi arány (CRT $=0)$ & 0,12 & 0,33 \\
Betétkivételi arány (CRT $>0)$ & 0,07 & 0,26 \\
\hline
\end{tabular}

Összesen 60 résztvevő volt, 30 nő és ugyanannyi férfi. A Gneezy-Potters [1997] által javasolt kockázatkerülési kérdésre átlagosan 5,6 eurót fektettek volna a kockázatos beruházásba, és látható, hogy a válaszok a lehetséges terjedelmet lefedték. A CRT-

\footnotetext{
${ }^{7}$ További részletekért lásd Frederick [2005] első táblázatát.
} 
pontszámok a Frederick [2005] cikkben ismertetett eredmények alapján a kevésbé ismert egyesült államokbeli egyetemeken kapott pontszámoknak felelnek meg.

A döntésekre áttérve, azt látjuk, hogy a harmadik pozícióban a döntések 10 százalékban vették ki a pénzüket a résztvevők. Ez azt sugallja, hogy az esetek túlnyomó részében felismerték, hogy domináns stratégia bennhagyni a pénzt. Az is látható azonban, hogy amikor nem volt stratégiai bizonytalanság, akkor ez az arány csupán 4 százalék volt, míg ellenkező esetben elérte a 17 százalékot. A leíró statisztikákból az is kiderül, hogy a CRT alapján legrosszabb kognitív képességekkel rendelkező résztvevők többször vették ki a pénzüket, mint a magasabb CRTpontszámot elért kísérleti alanyok. ${ }^{8}$ Ezek az egyszerü leíró statisztikák azt mutatják, hogy mind a stratégiai bizonytalanság, mind a kognitív képességek fontosak a részvevők döntéseinek megértéséhez.

A 3. táblázatban a CRT-pontszámok szerint bontva is megmutatjuk azt, hogy adott CRT-pontszámot elérö játékosok közül hány százalék vette ki, illetve hagyta bent a pénzét a bankban. Ezek az adatok alátámasztják, illetve pontosítják a leíró statisztikákat.

\section{3. táblázat}

A döntések százalékos megoszlása adott CRT-pontszám mellett

Döntés

Helyes válaszok száma a CRT-ben

$\begin{array}{llll}0 & 1 & 2 & 3\end{array}$

a) Az összes megfigyelést figyelembe véve

\begin{tabular}{lrrrr} 
Kiveszi a pénzét & 12,04 & 12,50 & 7,89 & 0,00 \\
Bennhagyja a pénzét & 87,96 & 87,50 & 92,11 & 100,00 \\
\hline b) Nincs stratégiai bizonytalanság & & & & 0,00 \\
Kiveszi a pénzét & 1,94 & 11,11 & 10,00 & 100,00 \\
Bennhagyja a pénzét & 98,06 & 88,89 & 90,00 & \\
\hline c) Van stratégiai bizonytalanság & & & & 0,00 \\
Kiveszi a pénzét & 21,24 & 14,29 & 5,56 & 100,00 \\
Bennhagyja a pénzét & 78,76 & 85,71 & 94,44 &
\end{tabular}

A 3. táblázat összes megfigyelést tartalmazó a) része azt mutatja, hogy a magasabb CRT-pontszámot elérő kísérleti alanyok kevésbé veszik ki a pénzüket. A pénzkivételi arányokat összehasonlítva az arányteszt (lásd a Függelék F1. táblázatában) csak a CRT $=0$ versus $\mathrm{CRT}=3$, illetve a $\mathrm{CRT}=1$ versus $\mathrm{CRT}=3$ mutat szignifikáns különbségeket 5 százalékos szignifikanciaszint mellett. ${ }^{9}$ A 3. táblázat b) része

\footnotetext{
${ }^{8}$ Természetesen másképp is csoportosíthatjuk a résztvevőket. Ha a maximális pontszámot elérőket $(\mathrm{CRT}=3)$ hasonlítjuk össze a kevesebb helyes választ adókkal, akkor azt látjuk, hogy az első csoportba tartozók sose vették ki a pénzüket, míg a második csoportba tartozóknál a betétkivételi arány 11 százalék.

${ }^{9} \mathrm{Az}$ itt tárgyalt statisztikai tesztek p-értékei a Függelék F1. táblázatában találhatók.
} 
a stratégiai bizonytalanság hiánya melletti adatokat tartalmazza, és ott kevésbé egyértelmü a magasabb CRT-pontszám hatása, sőt a pénzkivétel növekszik, amikor a CRT 0-ról 1-re növekszik. Ez a növekedés, illetve a CRT $=0$ és a CRT $=2$ összehasonlításakor mutat az arányteszt szignifikáns különbségeket 5 százalékos szignifikanciaszint mellett. A helyzet azonban egyértelmünek tünik a 3. táblázat c) részében, amely a stratégiai bizonytalanság melletti megfigyeléseket tartalmazza. Itt a CRT minden egyes növekedése a pénzkivételek egyértelmű csökkenésével jár. $\mathrm{Az}$ arányteszt 5 százalékos szignifikanciaszint mellett csak a CRT $=0$ és a CRT $=3$ összehasonlításakor mutat szignifikáns különbséget. ${ }^{10}$ Összességében ezen adatok és tesztek is azt sugallják, hogy a CRT-pontszámnak van hatása, ami a stratégiai bizonytalanság mellett jelentkezik.

A döntések alaposabb értelmezéséhez egy logit modellt hívtunk segítségül, amelyben a függő változó annak a valószínüsége, hogy a harmadik helyen döntő betétes kiveszi a pénzét. Mivel a játékosok 15 körön keresztül döntöttek, és a korábbi tapasztalatok befolyásolhatták a döntéseiket (hiszen minden kör végén információt kaptak a kifizetésükről és arról, hogy hányan vették ki a pénzüket), ezért Garratt-Keister [2009]-t követve mi is definiálunk egy History nevü változót, amely azt mutatja, hogy az adott résztvevő a korábbi körök mekkora hányadában volt olyan helyzetben, hogy a másik türelmes játékos kivette a pénzét. Az ökonometriai elemzésben figyelembe vesszük a 2. táblázatban bemutatott szociodemográfiai jellemzőket is. A kognitív képességek estében az $I_{\mathrm{CRT}}$ kétértékü változó értéke 1 , ha CRT $>0$, és nulla egyébként. ${ }^{11}$ A stratégiai bizonytalanság megragadásához is definiáltunk egy kétértékủ változót, $I_{\mathrm{SU}}{ }^{-t}$. Ennek értéke 1, ha fennáll stratégiai bizonytalanság, és nulla különben. A kognitív képességek és a stratégiai bizonytalanság között interakciót Ai-Norton [2003] alapján becsültük. A zárójelben a Bell-McCaffrey [2002] módszerrel korrigált linearizált (biased reduced linearization) standard hibákat tüntettük fel. Az eredmények a 4. táblázatban találhatók.

Három specifikációt mutatunk be. Az elsőbe az összes megfigyelést bevettük, majd a következő kettőben csak a stratégiai bizonytalanság által nem jellemzett, illetve jellemzett eseteket tekintettük. Ez az elemzés is azt sugallja, hogy a kognitív képességek hatnak a résztvevők döntéseire, de csak stratégiai bizonytalanság esetén. Az első regresszióban a stratégiai bizonytalanság kétértékủ változója, továbbá a stratégiai bizonytalanság és a CRT interakciója is szignifikáns. A stratégiai bizonytalanság megnöveli annak a valószínűségét, hogy az utolsó helyen döntő résztvevők kivegyék a pénzüket, azonban a jó kognitív képességgel rendelkezőknél ez a hatás kevésbé van jelen.

Szétválasztottuk azokat az eseteket, ahol nincs, és ahol van stratégiai bizonytalanság, hogy jobban megértsük e tényező szerepét. Amikor nincs stratégiai bizonytalanság, akkor könnyebb felismerni a domináns stratégiát, és ekkor a CRT-nek nincs

\footnotetext{
${ }^{10}$ Amikor a megfigyeléseket megbontjuk a stratégiai bizonytalanság szerint, nagyon lecsökken a CRT $>0$ elemszáma. Egyik esetben sincs adott CRT $>0$ mellett 20-nál több megfigyelésünk. Ez magyarázhatja, hogy kevés a szignifikáns különbség.

${ }^{11}$ Az eredmények nem változnak kvalitatíve, ha a fenti kétértékủ változó helyett a CRT-pontszámokat használjuk.
} 
4. táblázat

Marginális hatások a logit modell alapján

Függő változó: a harmadik helyen döntő türelmes betétes kiveszi-e a pénzét?

\begin{tabular}{lccc}
\hline & Összevont adatok & $\begin{array}{c}\text { Nincs stratégiai } \\
\text { bizonytalanság }\end{array}$ & $\begin{array}{c}\text { Van stratégiai } \\
\text { bizonytalanság }\end{array}$ \\
\hline HistoRY & $-0,178$ & $-0,048$ & $-0,229$ \\
KocKázATKERÜLÉs & $(0,133)$ & $(0,044)$ & $(0,205)$ \\
NEM $(=1$, ha nő $)$ & $-0,002$ & 0,0002 & $-0,009$ \\
Kognitív képességek $\left(I_{\text {CRT }}\right)$ & $(0,006)$ & $(0,001)$ & $(0,014)$ \\
Stratégiai & 0,009 & 0,011 & $-0,040$ \\
bizonytalanság $\left(I_{\text {SU }}\right)$ & $(0,033)$ & $(0,013)$ & $(0,059)$ \\
$I_{\text {CRT }} \times I_{\text {SU }}$ & 0,126 & 0,032 & $-0,154^{* * *}$ \\
\hline Megfigyelések száma & $(0,033)$ & $(0,035)$ & $(0,051)$ \\
\hline
\end{tabular}

Megjegyzés: zárójelben a Bell-McCaffrey [2002] módszerrel korrigált linearizált (biased reduced linearization) standard hibák.

${ }^{\star * *} p<0,01,{ }^{* *} p<0,05,{ }^{*} p<0,1$.

prediktív ereje $(p=0,361)$. Ellenben a CRT szignifikáns $(p=0,003)$, amikor van stratégiai bizonytalanság. Azon résztvevők, akiknek pozitív volt a CRT-pontszámuk, 15 százalékkal kisebb valószínúséggel vették ki a pénzüket, mint azok, akik egyetlen helyes választ sem adtak a CRT-ben, ceteris paribus.

Megvizsgáltuk a döntéseket olyan szempontból is, hogy adott résztvevő esetén a stratégiai bizonytalanság mellett és annak hiányában hozott döntések közötti különbség hogyan függ össze a kognitív képességekkel. Konkrétan, megnéztük a betétkivételi gyakoriságot a két esetben, és kiszámítottuk a különbséget. Minél nagyobb a különbség, annál inkább reagál az adott kísérleti alany a stratégiai bizonytalanságra. Ezen különbség és a CRT-pontszám közötti Spearman-féle korreláció $(\rho)$ azt mutatja, hogy a két dolog negatív relációban áll ( $\rho=-0,271, p=0,059)$, azaz minél jobb kognitív képességekkel rendelkezik egy résztvevö, annál kevésbé változnak a döntései a stratégiai bizonytalanság függvényében.

A kognitív képességek és a stratégiai bizonytalanság mellett felmerülhetnek más magyarázatok is, melyek segítségével megérthető a harmadik pozícióban döntést hozó betétesek választásai. Ha például a résztvevőket hajtja bizonyos alkalmazkodási preferencia (preference for conformity - Bikhchandani és szerzötársai [1998]), akkor azt várhatjuk, hogy az utolsóként döntő betétes utánozza az előtte döntést hozó betéteseket. Ekkor azonban azt várnánk, hogy két betétkivételt megfigyelö betétes inkább kivegye a pénzét, mint az olyan betétes a harmadik pozícióban, aki csupán azt látja, hogy egy korábbi betétes vette ki a pénzét a bankból. Az adatok azonban azt mutatják, 
hogy ez nem jó magyarázat. Ugyanis míg két megfigyelt betétkivétel után senki se vette ki a pénzét a harmadik pozícióban, addig 17 százalék kivette, amikor csak egy korábbi betétest figyelt meg, aki kivette a pénzét.

Megjegyezzük, hogy a logit modell elsősorban nagymintás becslésekre teljesít igazán jól, így némi fenntartással kell fogadni az eredményeket. A bemutatott leíró statisztikákkal együtt azonban úgy tủnik, hogy a kognitív képességeknek van hatásuk a betétesi döntésekre stratégiai bizonytalanság esetén, legalábbis a mi kísérleti környezetünkben.

\section{Konklúzió}

E tanulmányban a kognitív képességek prediktív erejét vizsgáltuk egy speciális pénzügyi döntés kapcsán, amit eddig még nem érintett a kutatás. Azt néztük, hogy kísérleti környezetben a betétesek optimális döntéseket hoznak-e olyan esetben, amikor egyértelműen kikövetkeztethető, hogy mi a legjobb döntés. A kísérlet során használt játék Diamond-Dybvig [1983] klasszikus tanulmányára épült, amit kiterjesztettünk oly módon, hogy a betétesek megfigyelhetik mások döntéseit is az információs struktúra függvényében. Ebben a játékban a betétesek egymás után döntenek, és a harmadik helyen, azaz utolsóként döntő betétesnek domináns stratégiája van (ha nem érte likviditási sokk). E betétes legjobb döntése az, ha attól függetlenül bennhagyja a pénzét a bankban, hogy az előtte döntést hozó betétesek mit tettek, illetve mit lehet megfigyelni. A korábbi döntések megfigyelhetősége fontos, ugyanis attól függően, hogy mit figyelhet meg az utolsóként döntő betétes, egyes esetekben fennáll a stratégiai bizonytalanság, míg más esetekben nem.

Az eredmények azt mutatják, hogy a kísérletben részt vevők túlnyomó többsége a domináns stratégiát választotta, azaz bennhagyták a pénzüket a bankban. A korábbi döntések megfigyelése számít, mivel stratégiai bizonytalanság esetén gyakrabban veszik ki a pénzüket a résztvevők. Ilyen esetekben a CRT-nek van prediktív ereje, ugyanis a teszt alapján jobb kognitív képességekkel rendelkező kísérleti alanyok könnyebben felismerték a domináns stratégiát, és ritkábban vették ki a pénzüket a bankból. Más a helyzet azonban akkor, amikor nem áll fenn a stratégiai bizonytalanság, ugyanis ekkor a CRT nem segít annak megértésében, hogy ki veszi ki a pénzét a bankból.

Az eredményeink illeszkednek ahhoz az ismertetett irodalomhoz, amely pénzügyi környezetben dokumentálja a nem optimális döntéseket, illetve azokat kognitív képességekhez kapcsolja. Konkrétabban a cikk a bankroham-irodalomhoz kapcsolódik, kísérleti módszertannal vizsgálva bizonyos betétesi döntéseket. Kísérletről lévén szó, felmerül a külső érvényesség kérdése. ${ }^{12}$ Azt találjuk, hogy a kognitív képességek szerepet játszhatnak a nem optimális betétesi döntésekben. Arról azonban semmit sem tudunk mondani, hogy ez a probléma mennyire súlyos a valós életben, ezért nem is kívánunk az eredményeinkből túlzó következtetéseket levonni. A szívünkhöz legközelebb álló értelmezés szerint az a tény, hogy egy egyszerü, háromszereplös imitált banki környezetben

\footnotetext{
${ }^{12}$ Az utóbbi években egyre több kísérletet végeznek a bankrohamok témakörében. Dufwenberg [2015] kritikus irodalmi áttekintése azt találja, hogy tanulhatunk az ilyen kísérletekből.
} 
találunk ilyen nem optimális döntéseket, azt sugallja, hogy a valós életben előforduló bonyolultabb helyzetekben, amelyekben véleményünk szerint még erösebb a stratégiai bizonytalanság, még inkább jellemzők a hasonló nem optimális döntések. Természetesen több kutatás szükséges, hogy megtudjuk, hogy ez az értelmezés helytálló-e.

\section{Hivatkozások}

AI, A.-Norton, E. C. [2003]: Interaction terms in logit and probit models. Economics Letters, Vol. 80. No. 1. 123-129. o. http://dx.doi.org/10.1016/s0165-1765(03)00032-6.

Ballinger, T. P.-Hudson, E.-Karkoviata, L.-Wilcox, N. T. [2011]: Saving behavior and cognitive abilities. Experimental Economics, Vol. 14. No. 3. 349-374. o. http://dx.doi. org/10.1007/s10683-010-9271-3.

BeLL, R. M.-McCAFFrey, D. F. [2002]: Bias reduction in standard errors for linear regression with multi-stage samples. Survey Methodology, Vol. 28. No. 2. 169-182. o.

Benjamin, D. J.-Brown, S. A.-Shapiro, J. M. [2013]: Who is 'behavioral'? Cognitive ability and anomalous preferences. Journal of the European Economic Association, Vol. 11. No. 6. 1231-1255. o. http://dx.doi.org/10.1111/jeea.12055.

Bergman, O.-Ellingsen, T.-Johannesson, M.-Svensson, C. [2010]: Anchoring and cognitive ability. Economics Letters, Vol. 107. No. 1. 66-68. o. http://dx.doi.org/10.1016/j. econlet.2009.12.028.

Bertrand, M.-Morse, A. [2011]: Information Disclosure, Cognitive Biases, and Payday Borrowing. Journal of Finance, Vol. 66. No. 6. 1865-1893. o. http://dx.doi.org/10.1111/j.15406261.2011.01698.x.

BiKHCHANDANI, S.-HiRshleifer, D.-WelCh, I. [1998]: Learning from the behavior of others: Conformity, fads, and informational cascades. The Journal of Economic Perspectives, Vol. 12. No. 3. 151-170. o. http://dx.doi.org/10.1257/jep.12.3.151.

Brañas-Garza, P.-García-Muñoz, T.-González, R. H. [2012]: Cognitive effort in the beauty contest game. Journal of Economic Behavior and Organization, Vol. 83. 2. 254-260. o. http://dx.doi.org/10.1016/j.jebo.2012.05.018.

Calomiris, C. W.-Mason, J. R. [2003]: Fundamentals, panics, and bank distress during the depression. American Economic Review, Vol. 93 No. 5. 1615-1647. o. http://dx.doi. org/10.1257/000282803322655473.

Carpenter, J.-Graham, M.-Wolf, J. [2013]: Cognitive Ability and Strategic Sophistication. Games and Economic Behavior, Vol. 80. No. 1. 115-130. o. http://dx.doi.org/10.1016/j. geb.2013.02.012.

CASARI, M.-Ham, J. C.-KaGEL, J. H. [2007]: Selection bias, demographic effects, and ability effects in common value auction experiments. The American Economic Review, Vol. 97. No. 4. 1278-1304. o. http://dx.doi.org/10.1257/aer.97.4.1278.

ChOI, J. J.-Laibson, D.-Madrian, B. C. [2011]: $\$ 100$ bills on the sidewalk: Suboptimal investment in 401 (k) plans. Review of Economics and Statistics, Vol. 93. No. 3. 748-763. o. http:// dx.doi.org/10.1162/rest_a_00100.

Christelis, D.-Jappelli, T.-Padula, M. [2010]: Cognitive abilities and portfolio choice. European Economic Review, Vol. 54. No. 1. 18-38. o. http://dx.doi.org/10.1016/j. euroecorev.2009.04.001.

Corgnet, B.-Hernán-González, R.-Kujal, P.-Porter, D. [2015]: The effect of earned versus house money on price bubble formation in experimental asset markets. Review 
of Finance, megjelenés alatt, Vol. 19. No. 4. 1455-1488. o. http://dx.doi.org/10.1093/ rof/rfu031.

Davison, L. K-Ramirez, C. D. [2014]: Local banking panics of the 1920s: Identification and determinants. Journal of Monetary Economics, Vol. 66. 164-177. o. http://dx.doi. org/10.1016/j.jmoneco.2014.05.001.

De Graeve, F.-Karas, A. [2014]: Evaluating theories of bank runs with heterogeneity restrictions. Journal of the European Economic Association, Vol. 12. No. 4. 969-996. o. http:// dx.doi.org/10.1111/jeea.12080.

Diamond, D. W.-Dybvig, P. H. [1983]: Bank runs, deposit insurance, and liquidity. The Journal of Political Economy, Vol. 91. No. 3. 401-419 o. http://dx.doi.org/10.1086/261155.

Dıјк, O. [2014]: Bank Run Psychology. Radboud University Nijmegen, Kézirat.

Dufwenberg, M. [2015]: Banking on Experiments? Journal of Economic Studies, megjelenés alatt.

EnNis, H. M. [2003]: Economic fundamentals and bank runs. FRB Richmond Economic Quarterly, Vol. 89. No. 2. 55-71. o.

Frederick, S. [2005]: Cognitive reflection and decision making. Journal of Economic Perspectives, Vol. 19. No. 4. 25-42. o. http://dx.doi.org/10.1257/089533005775196732.

Garratt, R.-Keister, T. [2009]: Bank runs as coordination failures: An experimental study. Journal of Economic Behavior \& Organization, Vol. 71. No. 2. 300-317. o. http:// dx.doi.org/10.1016/j.jebo.2009.03.009.

Gerardi, K.-Goette, L.-Meier, S. [2013]: Numerical ability predicts mortgage default. Proceedings of the National Academy of Sciences, Vol. 110. No. 28. 11267-11271. o. http:// dx.doi.org/10.1073/pnas.1220568110.

Gneezy, U.-Potters, J. [1997]: An experiment on risk taking and evaluation periods. The Quarterly Journal of Economics, Vol. 112. No. 2. 631-645. o. http://dx.doi. org/10.1162/003355397555217.

Gorton, G. [1988]: Banking panics and business cycles. Oxford Economic Papers, Vol. 40. No. 4. 751-781. o.

Gorton, G.-Metrick, A. [2012]: Securitized banking and the run on repo. Journal of Financial Economics, Vol. 104. No. 3. 425-451. o. http://dx.doi.org/10.1016/j.jfineco.2011.03.016.

Grinblatt, M.-Keloharju, M.-LinnainmaA, J. T. [2012]: IQ, trading behavior, and performance. Journal of Financial Economics, Vol. 104. No. 2. 339-362. o. http://dx.doi. org/10.1016/j.jfineco.2011.05.016.

Harmati László-LÁszló GézA-ZsámboKi Balázs [1996]: A pénzügyi rendszer információs problémái és a betétbiztosítás. Bankszemle, Vol. 40. No. 6. 1-29. o.

Heinemann, F.-Nagel, R.-Ockenfels, P. [2009]: Measuring Strategic Uncertainty in Coordination Games. Review of Economic Studies, Vol. 76. No. 1. 181-221. o. http://dx.doi. org/10.1111/j.1467-937x.2008.00512.x.

Insler, M.-Compton, J.-Schmitt, P. [2015]: The investment decisions of young adults under relaxed borrowing constraints. Journal of Behavioral and Experimental Economics, megjelenés alatt, http://dx.doi.org/10.1016/j.socec.2015.07.004.

IYER, R.-PURI, M. [2012]: Understanding bank runs: The Importance of depositor-bank relationships and networks. American Economic Review, Vol. 102. No. 2. 1414-1445. o. http:// dx.doi.org/10.1257/aer.102.4.1414.

Kelly, M.-O Grada, C. [2000]: Market contagion: Evidence from the panics of 1854 and 1857. American Economic Review, Vol. 90. No. 5. 1110-1124. o. http://dx.doi.org/10.1257/ aer.90.5.1110. 
Kiss Hubert János-Rodriguez-Lara, I.-Rosa-Garcia, A. [2014a]: Do social networks prevent or promote bank buns? Journal of Economic Behavior and Organization, Vol. 101. 87-99. o. http://dx.doi.org/10.1016/j.jebo.2014.01.019.

Kiss Hubert János-Rodriguez-Lara, I.-Rosa-Garcia, A. [2014b]: Do women panic more than men? An experimental analysis of financial decisions. Journal of Behavioral and Experimental Economics, Vol. 52. 40-51. o. http://dx.doi.org/10.1016/j.socec.2014.06.003.

Korniotis, G. M.-Kumar, A. [2013]: Do portfolio distortions reflect superior information or psychological biases? Journal of Financial and Quantitative Analysis, Vol. 48. No. 1. 1-45. o. http://dx.doi.org/10.1017/s0022109012000610.

Korniotis, G.-Kumar, A. [2010]: Cognitive Abilities and Financial Decisions. Megjelent: Baker, H. K.-Nofsinger, J. (szerk.): Behavioral Finance. John Wiley and Sons Inc., Hoboken, NJ, http://dx.doi.org/10.1002/9781118258415.ch30.

Livesey, B.-Menon, J. [2007]: Northern Rock Stock Tumbles Further Amid Run on Bank. Bloomberg Business, szeptember 17. http://www.bloomberg.com/apps/news?pid=newsarc hive\&sid=ax6oy1MsuSXA\&refer=home.

Oechssler, J.-Roider, A.-Schmitz, P. W. [2009]: Cognitive abilities and behavioral biases. Journal of Economic Behavior and Organization, Vol. 72. No. 1. 147-152. o. http://dx.doi. org/10.1016/j.jebo.2009.04.018.

Rydval, O.-Ortmann, A.-Ostatnicky, M. [2009]: Three very simple games and what it takes to solve them. Journal of Economic Behavior and Organization, Vol. 72. No. 1. 589601. o. http://dx.doi.org/10.1016/j.jebo.2009.05.011.

SHIN, H. S. [2009]: In Reflections on Northern Rock: The Bank Run that Heralded the Global Financial Crisis. Journal of Economic Perspectives, Vol. 23. No. 1 101-119. o. http:// dx.doi.org/10.1257/jep.23.1.101.

StARR, M.A.-Yilmaz, R. [2007]: Bank runs in emerging-market economies: Evidence from Turkey's special finance houses. Southern Economic Journal, 73. No. 4. 1112-1132. o.

Toplak, M. E.-West, R. F.-STANOvich, K. E. [2011]: The cognitive reflection test as a predictor of performance on heuristics-and-biases tasks. Memory and Cognition, Vol. 39. No. 7. 1275-1289. o. http://dx.doi.org/10.3758/s13421-011-0104-1.

Van Rooij, M. C.-Lusardi, A.-Alessie, R. J. [2011]: Financial literacy and retirement planning in the Netherlands. Journal of Economic Psychology, Vol. 32. No. 4. 593-608. o. http:// dx.doi.org/10.1016/j.joep.2011.02.004.

Wallace, N. [1988]: Another attempt to explain an illiquid banking system: the Diamond and Dybvig model with sequential service taken seriously. Federal Reserve Bank Minneapolis Quarterly Review, Vol. 12. No. 4.3-16. o.

\section{Függelék}

Az 1047. oldalon lévő kép egy olyan döntési szituációt mutat, amelyet a kísérletben részt vevők láthattak. Ezen a harmadik betétes mindkét korábbi döntést megfigyeli. Az ábrán szereplő kérdőjel azt jelzi, hogy a harmadik betétes nem tudja, hogy a második betétes látja-e azt, hogy miként döntött az első betétes. Ez azt fejezi ki, hogy a betétesek csak a saját éleiket ismerik. A jelen tanulmány szempontjából ennek a részletnek nincs jelentősége. 
A harmadik pozícióban vagy.

Sujeto: 10 - Secc 1 - Group: 3 - Type:1 - llet 31 -auxllet 3

Harmadikként érkezel a bankba, és azt látod, hogy az elsõ és a második egyén kivette a pénzét. Most neked kell döntened, hogy bennhagyod-e a pénzed vagy inkább kiveszed.

\section{Mit teszel?}

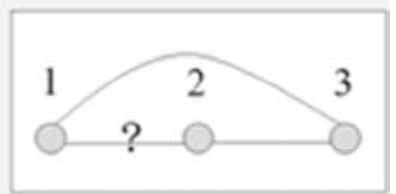

\section{Kiveszem \\ Bennhagyom}

Recuerda que el agente simulado por ordenador siempre retirará su dinero del banco.

Las ganancias dependerán de lo que tú y el otro agente decidáis hacer.

(i) Si ambos decidis esperar, obtendrás 140 ECUs.

(ii) Si de los dos, tú eres el único en retirar, te llevarás 100 ECUs.

(iii) Si de los dos, tú eres el único en esperar, cobrarás 60 ECUs.

Megjegyzés: az ábra alsó része a kifizetéseket magyarázza el a döntések függvényében.

\section{F1. táblázat}

Arányteszt $\left(H_{a}\right.$ : diff $\left.>0\right) p$-értékei

$$
\mathrm{CRT}=0 \quad \mathrm{CRT}=1 \quad \mathrm{CRT}=2
$$

Összes megfigyelés
$\mathrm{CRT}=0$
$\mathrm{CRT}=1$
$\mathrm{CRT}=2$
$\mathrm{CRT}=3$

n. SZ.

n. Sz.

$* *$

n. SZ.

Nincs stratégiai bizonytalanság
$\mathrm{CRT}=0$
$\mathrm{CRT}=1$
$\mathrm{CRT}=2$
$\mathrm{CRT}=3$

n. sz. n. sz.

n. sZ.

Van stratégiai bizonytalanság
$\mathrm{CRT}=0$
$\mathrm{CRT}=1$
$\mathrm{CRT}=2$
$\mathrm{CRT}=3$

n. SZ.

*

n. sz.

$* *$

n. sz.

n. sz. $=$ nem szignifikáns. ${ }^{* *} p<0,01,{ }^{* *} p<0,05,{ }^{*} p<0,1$. 